\title{
Kitozán hatóanyagú orrtampon tulajdonságainak vizsgálata állatkísérletes modellen
}

\author{
Piski Zalán dr. ${ }^{1}$ - Gerlinger Imre dr. ${ }^{1}$ - Tóth Eszter dr. ${ }^{2}$ \\ Háromi István dr. ${ }^{1}$ - Nepp Nelli dr. ${ }^{1}$ - Lujber László dr. ${ }^{1}$ \\ ${ }^{1}$ Pécsi Tudományegyetem, Általános Orvostudományi Kar, Klinikai Központ, \\ Fül-Orr-Gégészeti és Fej-Nyaksebészeti Klinika, Pécs \\ ${ }^{2}$ Magyar Honvédség Egészségügyi Központ, Fül-orr-gége és Fej-nyaksebészeti Osztály, Budapest
}

Bevezetés: Az endoszkópos melléküregmütétek során alkalmazott orrtamponáló módszerek hatékonysága máig ellentmondásos témakör az irodalomban.

Célkitüzés: Egy új típusú, kitozánt tartalmazó orrtamponnak a gyógyulási folyamatra gyakorolt hatását vizsgáltuk állatkísérletes modellen.

Módszer: Vizsgálatunkban 10 nyúlon standard nyálkahártya-sérülést okoztunk, kétoldali endoszkópos orrüregi beavatkozás során. Az egyik orrfélbe kitozán orrtampont helyeztünk, míg a másik orrfél tamponálás nélkül maradt. Az eredmények értékelése a posztoperatív 12. héten történt orrendoszkópos vizsgálatokkal, illetve szövetmintavétellel. A szövetmintákat pásztázó elektronmikroszkóppal is vizsgáltuk, ennek során a csillókkal nem rendelkező vagy elhalt hámsejteknek az épen maradt hámsejtekhez viszonyított arányát százalékban határoztuk meg. Orrendoszkópiával a nyálkahártya ödémáját, pörkösödését és az orrváladék jellegét, valamint az adhaesioképződés mértékét vizsgáltuk. A tünetek súlyosságától függően 0-tól 3-ig terjedő pontszámokat osztottunk ki Berlucchi és mtsai pontozási rendszerének módosításával. A magasabb pontszámok jelezték a kedvezőtlenebb állapotot.

Eredmények: Az adhaesiót vizsgálva a nem tamponált orrfeleknél mindössze l pont adódott (átlag: 0,1; standard deviáció $[\mathrm{SD}]: 0,32)$, míg a tamponált oldalon egyáltalán nem jelentkezett ez a tünet. A nem tamponált orrfelek pörkösödése 1 ponttal bizonyult kevesebbnek (9, átlag: 0,90; SD: 0,74), mint a tamponált orrfélnél (10, átlag 1,00; SD: 0,82$)$. Orrváladék és nyálkahártya-ödéma nem volt észlelhető. Az elektronmikroszkópos vizsgálat alapján a százalékos értékek átlaga a tamponált oldalon 22,06\% (SD: 0,25), míg a nem tamponált oldalon 36,1 1\% (SD: 0,48) volt. A különbségek nem érték el a szignifikancia szintjét $(\mathrm{p}=0,806)$.

Következtetés: A kitozántampon vizsgálata során egyik állatban sem tapasztaltunk mútéti szövődményt. A tamponált és a tampon nélküli orrfelek nyálkahártyájának gyógyulása között nincs szignifikáns különbség ezen állatkísérletes modell alapján.

Orv Hetil. 2018; 159(47): 1981-1987.

Kulcsszavak: kitozán, felszívódó orrtampon, funkcionális endoszkópos melléküregmútét, orrtamponálás, PosiSep

\section{Evaluation of chitosan-based nasal dressing in animal model}

Introduction: The usefulness of nasal packing after endoscopic sinus surgery is still debated in the literature. Aim: Our aim was to evaluate the effects of a new chitosan-based nasal dressing in animal model.

Methods: Standard mucosal damage was caused in both nostrils during endoscope-assisted procedure in ten rabbits. Chitosan nasal packing was inserted in a randomly selected nasal fossa of each animal, while the other side was left unpacked. Symptoms were evaluated during nasal endoscopy on the 12th postoperative week. The degree of mucosal oedema, crusting, adhesions and the nasal discharge were observed according to the modification of the grading system of Berlucchi et al. The higher scores indicated the worse complaints.

Results: Assessing the adhesion formation, 1 point was given (mean: 0.1; standard deviation [SD]: 0.32) for the unpacked side, while in the tamponated side no adhesion formation was observed. The total score of crusting in the non-packed side was lower with 1 point (total score: 9, mean: 0.90; SD: 0.74) than in the chitosan side (total score: 10, mean 1.00; SD: 0.82). Discharge or mucosal oedema were not observed during the follow-up period. The mean rate, measured with electronmicroscopy, was $22.06 \%$ (SD: 0.25 ) in the chitosan side, while in the non-packed side it was $36.11 \%$ (SD: 0.48$)$. The differences did not show any significance $(\mathrm{p}=0.806)$. 
Conclusion: During the examinations, none of the animals suffered complications. The symptoms of the packed and the non-packed nasal cavities did not differ significantly on the basis of our examinations.

Keywords: absorbable nasal packing, chitosan, functional endoscopic sinus surgery, nasal packing, PosiSep

Piski Z, Gerlinger I, Tóth E, Háromi I, Nepp N, Lujber L. [Evaluation of chitosan-based nasal dressing in animal model]. Orv Hetil. 2018; 159(47): 1981-1987.

(Beérkezett: 2018. május 29.; elfogadva: 2018. június 19.)

\section{Rövidítés}

FESS = (functional endoscopic sinus surgery) funkcionális endoszkópos orrmelléküreg-mütét; SD = standard deviáció

Több mint 30 év telt el a funkcionális endoszkópos orrmelléküreg-sebészet (FESS) alapelveinek és alapvető mütéttechnikai lépeseinek kidolgozása óta [1]. Azonban a mai napig sincs egységes szemlélet a mütét utáni orrtamponálás kérdéskörét illetően. Bár első látásra érdektelen kérdésnek tünhet, a teljes gyógyulási folyamatot, valamint az operáció funkcionális eredményességét alapvetően határozza meg a körültekintően megtervezett, mútét utáni orrtamponálás. Közlemények támasztják alá, hogy a beteg posztoperatív fájdalmát és a mútéttel kapcsolatos elégedettségét is nagyban befolyásolja az orrtamponálás mikéntje [2]. Az endoszkópos melléküregmưtétek esetében speciális helyzet áll elő abban a tekintetben, hogy nem lehet szó a hagyományos értelemben vett sebzárásról, „suturáról”. A műtéti terület végső soron az orrlyukon keresztül a külvilággal kapcsolatban marad, melynek valamiféle ellátására jogos igény mutatkozik. Egyszerü megoldásnak tünik tehát az orrüreg szoros tamponálása, mely a posztoperatív vérzés problémáját látszólag megoldja, ám a rinológiai mútétet végző szakember ennél több szempont figyelembevételére kényszerül. A sebgyógyulás során a vérzésveszély mellett jellemző lehet az orrüregi nyálkahártya pörkösödése, ödémája és a váladékozás. A későbbiekben, részben e jelenségek hatására, a kialakított terek átjárhatósága romlik, adhaesiók jöhetnek létre, jelentősen csökkentve a mütét eredményességét. Az ideális orrtamponáddal szemben tehát a következő elvárásaink lehetnek: 1. gyors intraoperatív vérzéscsillapítás, 2. tartós posztoperatív haemostasis, 3. az adhaesiók kialakulásának kiküszöbölése, 4. a granuláció és a pörkösödés megelőzése, 5. jól funkcionáló csillószőrös reepithelisatio elősegítése, 6 . mikrobiológiai biztonság, 7. hipoallergenitás, 8. az ostiomeatalis komplexum átjárhatóságának fenntartása, 9. kényelem.

Az orr tamponálásakor azonban fontos megjegyezni, hogy a behelyezett tampont egyszer mindenképpen el is kell majd távolítani az orrüregből. Ekkor jellemzően a sebfelületbe ragadt tampon a betegnek okozott gyakran igen erôs fájdalom mellett, jelentős mennyiségű gyógyuló nyálkahártyát magával rántva távozik, csaknem friss mütéti területet hagyva maga után az orrüregben. Az újabb típusú felszívódó tamponáló megoldások használatával természetesen ez a jelenség elkerülhető, azonban a jelenleg alkalmazott felszívódó orrtamponok sem felelnek meg maradéktalanul a fent megfogalmazott kritériumoknak. Egyes közlemények ugyanis rámutatnak, hogy a tamponálás elhagyása esetén sem jelentkeznek szignifikánsan kedvezőtlenebb viszonyok az orrüregben; ennek kapcsán egyre többen már azt a kérdést is feszegetik, hogy egyáltalán szükséges-e minden beteg esetében tamponálni az orrot FESS után $[3,4]$. Napjainkban a különböző orrtamponok széles választéka található meg a kereskedelmi forgalomban. A legelterjedtebb a hagyományos, nem felszívódó tamponok használata, emiatt jelenleg még mindig nem gyưlt össze elégséges tapasztalat az új típusú, teljesen lebomló orrtamponokkal kapcsolatban. Számos természetes és mesterséges gélt, habot, illetve szilárd halmazállapotú anyagot használhatunk orrtamponként, de nem minden tampon esetében jelent meg olyan közlemény, amely nagy beteganyagon, tudományos igényességgel ismertette volna az eredményeket (1. táblázat). Amennyiben viszont mégis szükséges az orr tamponálása, a biológiailag lebomló anyagok használata látszólag előnyösebbnek tűnik, mivel nincs szükség fizikai eltávolításukra, ami számos könnyebbséget jelent a beteg, illetve az egészségügyi személyzet számára. A felszívódó anyagokkal ugyanis elkerülhetjük a sokszor a mútéttel kapcsolatban legrosszabb emlékként megmaradó tamponeltávolítást és a vele járó fájdalmat $[5,6]$, valamint a következményes vérzéses szövődményeket, a nyálkahártya újbóli sérülését és az ezekből fakadó, esetlegesen hosszabb hospitalizációt [7-10]. Emellett azon-

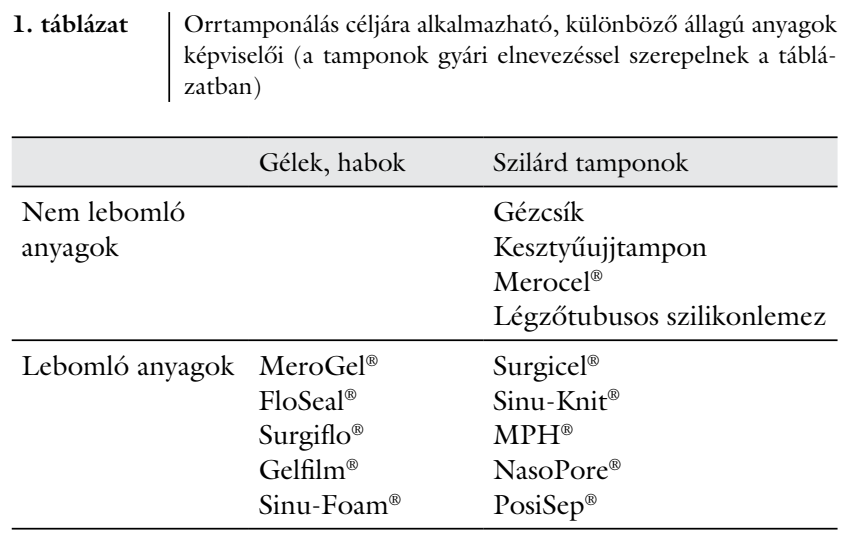


ban igazolni szükséges, hogy a felszívódó anyagok orrtamponként történő alkalmazása egyéb szempontok figyelembevétele mellett is felülmúlja-e a konvencionális megoldásokat, és ha igen, mely típusok használata jár a legnagyobb előnnyel. Ebből a szempontból rendkívül fontos a mútét utáni pörkösödés, nyálkahártya-ödéma, hegesedés vagy a váladékozás mértékének vizsgálata, illetve az újonnan kialakított terek átjárhatóságának, intaktságának ellenőrzése és nem utolsósorban a vérzéscsillapító hatás felmérése. Ezek a jelenségek a légúti nyálkahártya regenerációjának folyamatáról adnak visszajelzést, melyet a mütét utáni orrtamponálás valószínúleg alapvetően befolyásol [2]. Az új típusú, felszívódó orrtamponok egyre szélesedő választékából a PosiSep (Hemostasis, Saint Paul, MN, Amerikai Egyesült Államok) tampon került munkacsoportunk látókörébe. Ez a termék ugyanis kitozánt tartalmaz, mely anyag előnyös tulajdonságai - rendkívüli haemostaticus képessége , illetve az adhaesioképződés eredményes megelőzése - már ismertek, de ez idáig mindössze két közleményben számoltak be részletesen az alkalmazása során nyert eredményekről [11, 12].

Jelen állatkísérletes vizsgálatunkban orrendoszkópos és elektronmikroszkópos szövettani vizsgálatokkal a nyálkahártya regenerációs folyamatának és a szövődmények alakulásának megfigyelését tûztük ki célul egy új típusú, kitozántartalmú orrtampon használata kapcsán.

\section{Módszer}

Vizsgálatunkban nyúlmodellt alkalmaztunk. Választásunk azért esett erre az állatra, mert könnyen beszerezhető, költséghatékony, és egyszerübben tartható, mint az egyébként kiváló rinológiai állatmodellként használható birka vagy sertés. Felmerülhet továbbá a még könynyebben kezelhető és igen olcsó patkány vagy egér alkalmazása is. Ezek esetében azonban az orrüregek mérete korlátozza az operatőrt, akinek rendkívül kényelmetlen körülmények között kellene elvégeznie a beavatkozásokat.

Seduxen-szedációt követő Calypsol általános érzéstelenítésben végeztünk beavatkozást 10 darab új-zélandi fehér nyúlon. A mütét során mindkét orrüregben felkerestük a lateralis orrfalat endoszkóp biztosította nagyítás és széles látószög mellett. A nyúl orrüregi anatómiája lényegesen bonyolultabb az emberénél, azonban ebben a fajban is elkülöníthető nagyjából 3 orrkagylórendszer. Az utóbbiak közül a középső orrkagylórendszert hideg eszközzel, élesen reszekáltuk. Ezt a beavatkozást tekintettük standard mütéti sérülésnek az orrüregi nyálkahártyán. A mútét utolsó lépéseként az egyik random módon kiválasztott orrfélbe PosiSep orrtampont helyeztünk. A tampon méretét az állat orrnyílásának megfelelő $5 \times 30$ mm-re csökkentettük. A másik orrfélbe nem helyeztünk tampont. A randomizációt a www.randomize.org online alkalmazás segítségével végeztük. Az operáció után az állatokat további kezelésben nem részesítettük, antibioti-
2. táblázat |Az endoszkópos vizsgálat értékelése

\begin{tabular}{|c|c|c|c|c|}
\hline \multicolumn{5}{|c|}{ Az endoszkópos betegvizsgálat értékelése } \\
\hline $\begin{array}{l}\text { Nyálkahártya- } \\
\text { ödéma }\end{array}$ & Nincs & $\begin{array}{l}\text { Enyhe } \\
\text { ödéma }\end{array}$ & $\begin{array}{l}\text { Súlyos } \\
\text { ödéma }\end{array}$ & Atrophia \\
\hline Pörkösödés & Nincs & Szigetszerü & Mérsékelt & Obtruáló \\
\hline Adhaesiók & Nincs & Szoliter & Többszörös & Obtruáló \\
\hline $\begin{array}{l}\text { Orrváladéko- } \\
\text { zás }\end{array}$ & $\begin{array}{l}\text { Normál } \\
\text { orrváladék }\end{array}$ & Serosus & $\begin{array}{l}\text { Seromuco- } \\
\text { sus }\end{array}$ & Purulens \\
\hline Pontszámok: & 0 & 1 & 2 & 3 \\
\hline
\end{tabular}

kumot nem alkalmaztunk. Így vártuk ki a teljes gyógyulási időnek meghatározott 12 hetes időintervallum végét. Ezt követően az első beavatkozással megegyező altatási módszerrel újabb endoszkópos mútétet végeztünk. Ennek során dokumentáltuk az orrüregi viszonyokat, és az alábbi paraméterek megfigyelésével gyưjtöttünk adatokat a posztoperatív állapotról: az orrváladék jellege, adhaesiók jelenléte, nyálkahártya-ödéma jelenléte, valamint a pörkösödés mértéke. A paramétereket Berlucchi és mtsai ajánlása szerint vizsgáltuk [13], 0-tól 3 pontig értékelve az orrüregi viszonyokat. Minden esetben a magasabb pontértékek jelentették a kedvezőtlenebb állapotot (2. táblázat). A fenti jelenségek egyikét sem észleltük az első mútét bevezető lépéseként végzett tájékozódó endoszkópos áttekintés során. Az endoszkópos áttekintést követően azonosítottuk a korábbi mútéti sebzés nyomán visszamaradt heges területet, és innen szövetmintát vettünk mindkét orrfél esetében. A mintákat a továbbiakban pásztázó elektronmikroszkópos feldolgozásnak vetettük alá. Az elektronmikroszkópos felvételek alapján észlelt jelenségek számszerúsítésének céljából a következő módszert alkalmaztuk: mivel a mütéti trauma leginkább a csillószőröket károsítja, megfigyelésünk során az ép csillószőrökkel rendelkező sejtek arányát vizsgáltuk. A 3000-szeres nagyításon átlagosan 35 négyzetmikron területü felületen lehet részletgazdag, nagy nagyítású képet látni a hámsejtekról, így minden vizsgált terület esetében könnyen megszámolható $50 \mathrm{db}$ ezekből. Az átvizsgált 50 hámsejt esetében megszámoltuk a csillóval nem rendelkező, illetve a láthatóan elhalt, vagy hiányzó sejteket, így meghatározható ezek aránya az átnézett területen. Minden mintánál három, 35 négyzetmikronos terület került átvizsgálásra. A károsodott sejtek arányának átlagértékeinek segítségével elemeztük a hám minőségét.

Az eredményeket statisztikai feldolgozás során Wilcoxon-teszt, Fisher-teszt és McNemar-teszt segítségével értékeltük. A statisztikai szignifikancia szintjét $\mathrm{p}<0,05$ értékben határoztuk meg.

\section{Eredmények}

Az állatok orrüregi statusának endoszkópos értékelése a mütét utáni 12 . héten történt. A vizsgálat során a pörkösödés, a nyálkahártya-ödéma, az adhaesiók és az orrvála- 
3. táblázat $\mid$ Az endoszkópos vizsgálat során észlelt tünetek pontértékei

\begin{tabular}{l|cc|cc}
\hline \multirow{2}{*}{ Alany } & \multicolumn{2}{|c|}{ Pörk } & \multicolumn{2}{c}{ Adhaesio } \\
& Tampon nélkül & Kitozán & Tampon nélkül & Kitozán \\
\cline { 2 - 5 } I. & 2,00 & 0,00 & 1,00 & 0,00 \\
II. & 0,00 & 0,00 & 0,00 & 0,00 \\
III. & 1,00 & 2,00 & 0,00 & 0,00 \\
IV. & 1,00 & 1,00 & 0,00 & 0,00 \\
V. & 0,00 & 1,00 & 0,00 & 0,00 \\
VI. & 0,00 & 1,00 & 0,00 & 0,00 \\
VII. & 1,00 & 2,00 & 0,00 & 0,00 \\
VIII. & 2,00 & 0,00 & 0,00 & 0,00 \\
IX. & 1,00 & 2,00 & 0,00 & 0,00 \\
X. & 1,00 & 1,00 & 0,00 & 0,00 \\
\hline Összesen & 9,00 & 10,00 & 1 & 0 \\
\hline Átlag & 0,90 & 1,00 & 0,10 & 0 \\
\hline SD & 0,737864787 & 0,816496581 & 0,316227766 & 0 \\
\hline
\end{tabular}

SD = standard deviáció

4. táblázat $\mid$ Az elektronmikroszkópos vizsgálat során megfigyelt, elhalt vagy megfelelő csillóborítással nem rendelkező hámsejtek aránya

\begin{tabular}{lcc}
\hline Alany & Kitozán & Tamponálás nélkül \\
\hline I. & $14,86 \%$ & $7,04 \%$ \\
II. & $0 \%$ & $100 \%$ \\
III. & Értékelhetetlen & $27,69 \%$ \\
IV. & $58,33 \%$ & $100 \%$ \\
V. & $80 \%$ & $100 \%$ \\
VI. & $12,67 \%$ & $0 \%$ \\
VII. & $0 \%$ & $4,00 \%$ \\
VIII. & $8,00 \%$ & $11,33 \%$ \\
IX. & $15,33 \%$ & $10 \%$ \\
X. & $9,33 \%$ & $10,67 \%$ \\
\hline Átlag & $22,06 \%$ & $36,11 \%$ \\
\hline
\end{tabular}

dék jelenléte képezte a megfigyelendő jelenségek csoportját.

A pörkösödést tekintve a nem tamponált orrfeleket vizsgálva összesen 9 tüneti pontszám adódott, így az átlagérték 0,90 volt (standard deviáció [SD]: 0,74). Ugyanezen szempont szerint a tamponált orrfélnél az összpontszám 10, az átlag pedig 1,00 volt (SD: 0,82)

$\mathrm{Az}$ adhaesio esetében a nem tamponált orrfeleknél összesen mindössze 1 pont adódott 0,1 -es átlagérték mellett (SD: 0,32). A kitozántampon oldalán nem volt észlelhető adhaesioképződés. A pörkösödés és az adhaesio esetében mért értékek különbsége nem érte el a szignifikancia szintjét $(\mathrm{p}=0,806)$.
A kevés, 0-tól különböző adat miatt külön kategóriába szedve is értékeltük az eredményeket a pontosabb statisztikai feldolgozás céljából. Ebben az esetben a csak 0 és az attól különböző értékek (igen-nem) szerepeltek a számításban. Ebben az esetben sem mértünk szignifikáns különbséget az orrfelek között $(\mathrm{p}=1,00)$.

A további orrtüneteket vizsgálva egyik állat esetében sem találtunk egyik orrfélben sem a normálistól eltérő váladékképződést vagy nyálkahártya-ödémát a mútét utáni harmadik hónap elteltével. Az eredményeket a 3. táblázat szemlélteti.

A pásztázó elektronmikroszkópos értékelés során a tamponált és a nem tamponált orrfeleket összehasonlítva a károsodott hámsejtek arányát százalékban adtuk meg. A tamponált oldalon a hámsejtek 22,06\%-át (SD: 0,25), míg a nem tamponált oldalon a 36,11\%-át (SD: 0,48 ) véleményeztük károsodottnak. Az elektronmikroszkópia segítségével megállapított hámkárosodás százalékos arányát az egyes állatok esetében a 4. táblázat szemlélteti. $\mathrm{Az}$ ép és a károsodott nyálkahártya-borítás pásztázó elektronmikroszkópos felvételen 250-szeres és 3000-szeres nagyításban az 1 . és 2. ábrán látható.

\section{Megbeszélés}

A kitozán egy természetes polimer, mely tengeri állatok kitinpáncéljából izolálható. Az utóbbi években született humán és állatkísérletes tanulmányok igen ígéretes haemostaticus anyagnak írják le a kitozánt, mely az adhaesioképződés megelőzésében is hatékony $[14,15]$. Az elóbbi tulajdonságát mi sem bizonyítja jobban, mint hogy az Egyesült Államok hadserege is kitozántartalmú kötszereket alkalmaz a harctéri ellátás során [16]. Antiadhezív tulajdonsága mellett a nyálkahártya epitheliumának gyorsabb és jobb minőségú regenerációját figyelték meg a használata során. Feltehetôleg fizikai barrierként gátolja a gyógyuló felszínek között a fibroblastmigrációt és a kollagéndepozíciót, így akadályozva a fibroblastok munkáját [17]. Az epithelsejtekre kifejtett kedvező hatásának pontos mechanizmusa azonban még nem teljesen tisztázott.

Az orrüregi nyálkahártya feladata igen sokrétű. A külvilág felől érkező levegő itt találkozik először a szervezettel, így a szennyező anyagok felfogása és eliminálása, illetve a külső levegő hőmérsékletének és páratartalmának optimalizálása alapvető fontosságú. Az orrüregen áthaladó levegő páratartalma átlagosan 40\%-ról - az orrgaratig jutva $-80 \%$-ra nő. Az orrüregben található szaglóhám az egyik legfontosabb érzékszervünk, és nem utolsósorban maga az orrüreg és a melléküregek a hangszín kialakításában is szerepet játszó rezonátortérként is funkcionálnak. Ezen feladatok ellátásához nélkülözhetetlenek a csillószőrös hámsejtek és a csillószőrök kifogástalan funkcionális állapota. Az orrváladék és az idegen anyagok garat felé történő továbbítása és a melléküregek drenázsa közvetlenül a csillómozgás eredménye, de e funkció károsodása a kialakuló kórállapoton keresztül vé- 


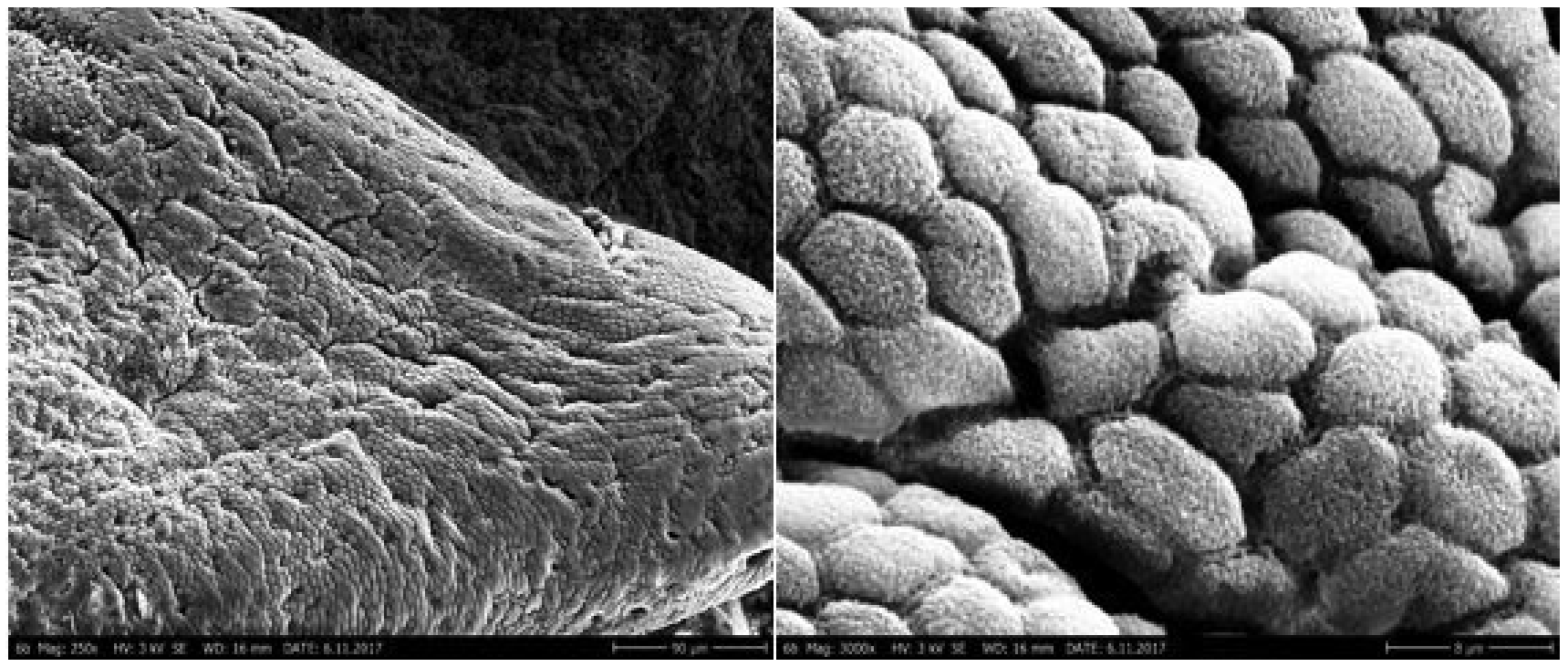

1. ábra | Ép nyálkahártya-borítás 250-szeres és 3000-szeres nagyítású elektronmikroszkópos felvételen

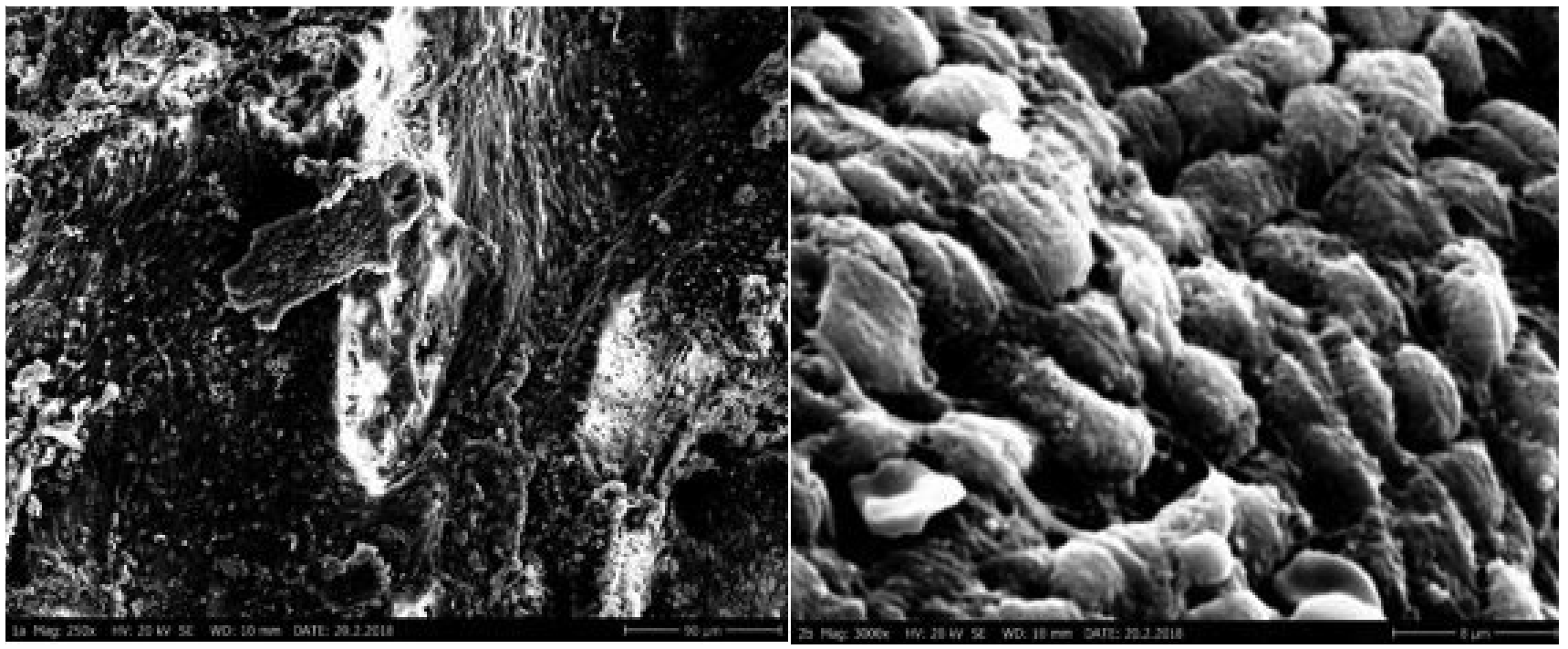

2. ábra | Károsodott nyálkahártya-borítás 250-szeres és 3000-szeres nagyítású elektronmikroszkópos felvételen

gül is minden orr- és melléküregi funkció romlását vagy akár teljes elvesztését okozhatja. Érthető tehát, hogy az egyik legfontosabb jelenség az orr és a melléküregek mútétjét követő gyógyulási periódus alatt a nyálkahártyaborítás regenerációja. A különböző orrtamponálási eljárások ezt a folyamatot jelentôsen befolyásolhatják. Ezen megoldások tudományos igényű vizsgálata klinikai beteganyagon, illetve az invazív eljárásokat igénylő kutatómódszerek esetében állatmodellen történhet [18-20]. A mútéten átesett betegek orrüregének alapos és rendszeres endoszkópos vizsgálata során juthatunk a kívánt adatokhoz. Különösen szerencsés ez esetben, hogy páros szerv lévén, az alanyok egyik-másik orrfelét különböző eljárásokkal tamponálhatjuk. Így egyazon betegben egymással hasonlíthatjuk össze a posztoperatív kép változását, az alkalmazott módszer hatékonyságát. Hasonló a helyzet az állatmodellen végzett vizsgálatok esetében, itt azonban többszörös szövettani mintavétel is lehetséges, mely igen értékes információt szolgáltat az alanyban lejátszódó folyamatokról. Ebben az esetben a nyálkahártyafelszín - a szövetminta mikroszkópos és elektronmikroszkópos elemzésével - még részletesebben vizsgálható. Ez a megoldás klinikai beteganyagon etikai kérdéseket vetne fel, mivel a gyógyult beteg „féltve őrzött” nyálkahártyafelszínét kellene ismét invazív módon megközelíteni. Az elóbbiek szellemében igen kevés közlemény született, kiemelendő azonban Wormald és mtsai tanulmánya, akik kitozánalapú gél hatásait vizsgálták [11]. Báránymodellen végzett kétoldali endoszkópos melléküregmútét során figyelték meg az orrüregi nyálkahártya változását. A tamponálás nélkül hagyott kontrollorrféllel összehasonlítva a polietilén-glikol, a rekombináns szöveti faktor és a kitozán-dextrán gél hatásait vizsgálták, endoszkópos és pásztázó elektronmikroszkópos mód- 
szerrel. Megállapították, hogy a rekombináns szöveti faktorhoz képest, a kitozán-dextránnal kezelt oldalon szignifikánsan kevesebb adhaesioképződés észlelhető, illetve a kitozán-dextrán tamponálás oldalán a ciliumok szignifikánsan nagyobb területen jelentek meg újra a 28. napon a nyálkahártya felszínén. Későbbi konrollon is szignifikánsan jobbnak ítélték a negatív kontrollhoz és a rekombináns szöveti faktorhoz képest a ciliumok minőségét.

Az orrüregi tamponok viselkedésével foglalkozó, humán beteganyagon végzett tanulmányok a leginkább az endoszkópos nyomon követés és a betegek szubjektív panaszainak felmérése során közlik a megfigyelt tüneteket. Chung és mtsai vizsgálatuk során szintén gél állagú kitozánt alkalmaztak, kezelés nélkül hagyott orrféllel kontrollálva az eredményeket [12]. Vizsgálták az azonnali vérzéscsillapító hatást, melynek alapján a kitozán a betegek 90,91\%-ában teljes haemostasist biztosított. Az adhaesioképződésre gyakorolt hatást vizsgálva a kitozán alkalmazása során szignifikánsan kisebb volt ennek a jelenségnek a mértéke.

Prospektív vizsgálatunk során kitozántartalmú, szilárd állagú orrtampon alkalmazásának középtávú eredményeit értékeltük állatmodellen. A nyulakon végzett beavatkozások során random módon kiválasztott orrfélben alkalmaztuk a tampont, melynek negatív kontrolljaként az ellenoldali, tamponálás nélkül hagyott orrfél szolgált. Az állatokat 12 hét elteltével vizsgáltuk, tehát a teljesen lezajlott gyógyulási folyamat végén értékeltük az eredményeket. A vizsgálat során egyik állatban sem tapasztaltunk nemkívánatos szövődményt. Az összességében is igen alacsony tüneti pontszámok, melyek a pörkösödés, de leginkább a váladékozás és a nyálkahártya-ödéma mértékét jelölik, arra utalnak, hogy 3 hónap alatt teljes mértékben lezajlott a gyógyulási folyamat. Az adhaesioképződés tekintetében mindössze 1 orrfélben adódott 1 pont értékű minimális tünet, de ez a jelenség egyébként sem a korai gyógyulási periódusra jellemző, hanem a késői sebgyógyulási zavar egyik megjelenési formája. Az adhaesiók leggyakoribb oka a sebészeti beavatkozás vagy a gyulladás. Az erek permeabilitásának megnövekedése során gyulladásos sejtek megjelenésén keresztül fibrinmátrix alakul ki, mely normális esetben természetes adhaesiolysis útján 2-3 napon belül lebomlik, és a heg adhaesioképződés nélkül gyógyul. Ha a fibrinolitikus aktivitás csökken, az így megmaradó fibrinszálak stabil adhaesióvá alakulnak, majd megjelennek a rostos alkotóelemek, a területen erek, idegek tünnek fel [21]. Ezek alapján valószínúsíthető, hogy a makroszkópos sebgyógyulás mellett már a reepithelisatio is végbemegy ennyi idő alatt. Ezért feltételeztük, hogy még későbbi mintavételezés során sem látnánk komplettebb restitúciót a nyálkahártyán. Az operált orrfelek endoszkópos megfigyelése során gyưjtött adatokból látható volt, hogy érdemi különbség nincs az észlelt tünetekben a tamponált és a nem tamponált oldal között, hiszen a minimális eltérések egyike sem közelítette meg a statisztikai szignifikancia szintjét. Bár az irodalomban megtalálható eredmények látszólag jelentősen különböznek a jelen közleményben ismertetettektől, ezen vizsgálatokban a követési idő mindössze 1-6 hét volt. Az adhaesioképződés azonban kezelés nélkül élethosszig fennmaradó eltérés, így a késóbbi kontrollok alkalmával is jelen kellett volna lennie. A jelen közleményben észlelt jelentősen kisebb mértékú adhézióképződés így feltehetőleg a nyúlmodell sajátosságai vagy a kevésbé radikális mútéti sebzés vagy mindkét ok miatt adódott. A 12. héten, tehát a feltételezett gyógyulási idő elteltével készített pásztázó elektronmikroszkópos vizsgálat során nyert adatok a nyálkahártya felületének mútét utáni végleges állapotát mutatják. Vizsgálatunk nem mutatott ugyan szignifikáns eltérést a két oldal között, a kitozántartalmú orrtamponnal kezelt orrfelekben mégis kisebb arányú volt a károsodott hámsejtek aránya. Bár nem igazolható egyértelmúen, hogy a kitozán eredményesebb csillószőr-regenerációt biztosít a nem tamponált oldalhoz képest, feltételezhető, hogy negatív irányban sem befolyásolja a gyógyulási folyamatot, ami nem minden tamponáló megoldásról mondható el teljes biztonsággal [22]. Vizsgálatunk során az irodalmi adatokhoz képest jelentősen komplettebb csillószőrös regenerációt észleltünk. Ennek oka feltehetőleg szintén az eltérő állatmodell alkalmazása és a jóval későbbi kontrollidőpont volt. A jelen vizsgálat korlátai között meg kell említenünk az alacsony esetszámot és a mintavétel nehézségét, valamint a mért értékek nagy szórását, mely a statisztikai értékelés megbízhatóságát korlátozhatta.

\section{Következtetés}

A szerzők véleménye szerint a kitozánnak az irodalomból ismert kiváló vérzéscsillapító tulajdonságát, illetve a szilárd halmazállapotú tamponok szerkezeti tulajdonságainak kedvező hatásait tekintve a kitozántampon öszszességében jó alternatívája lehet az orrüregi mútétek esetén alkalmazható megoldásoknak.

Anyagi támogatás: A közlemény megírása, illetve a kapcsolódó kutatómunka anyagi támogatásban nem részesült.

Szerzői munkamegosztás: P. Z.: A közlemény megírása, az állatmútétek operatőre. G. I., T. E.: Az eredmények feldolgozása, értelmezése. H. I.: Az állatmútétek operatőre, asszisztense. N. N.: Irodalmi áttekintés. L. L.: Vizsgálatvezető, az eredmények feldolgozása, értelmezése. A cikk végleges változatát valamennyi szerző elolvasta és jóváhagyta.

Érdekeltségek: A szerzőknek nincsenek érdekeltségeik. 


\section{Köszönetnyilvánítás}

A szerzők hálás köszönetüket fejezik ki Dr. Farkas Kornéliának, aki értékes munkájával a statisztikai feldolgozás során nyújtott felbecsülhetetlen segítséget, valamint Dusikné Szommer Zsuzsanna Dalmának az állatmútétek során végzett áldozatos munkájáért.

\section{Irodalom}

[1] Stammberger H, Posawetz W. Functional endoscopic sinus surgery. Concept, indications and results of the Messerklinger technique. Eur Arch Otorhinolaryngol. 1990; 247: 63-76.

[2] Weitzel EK, Wormald PJ. A scientific review of middle meatal packing/stents. Am J Rhinol. 2008; 22: 302-307.

[3] Orlandi RR, Lanza DC. Is nasal packing necessary following en doscopic sinus surgery? Laryngoscope 2004; 114: 1541-1544.

[4] Eliashar R, Gross M, Wohlgelernter J, et al. Packing in endoscopic sinus surgery: is it really required? Otolaryngol Head Neck Surg. 2006; 134: 276-279.

[5] von Schoenberg M, Robinson P, Ryan R. Nasal packing after routine nasal surgery - is it justified? J Laryngol Otol. 1993; 107: 902-905.

[6] Samad I, Stevens HE, Maloney A. The efficacy of nasal septal surgery. J Otolaryngol. 1992; 21: 88-91.

[7] Pomerantz J, Dutton JM. Platelet gel for endoscopic sinus surgery. Ann Otol Rhinol Laryngol. 2005; 114: 699-704.

[8] Vaiman M, Eviatar E, Segal S. The use of fibrin glue as haemostatic in endonasal operations: a prospective, randomized study. Rhinology 2002; 40: 185-188.

[9] Vaiman M, Eviatar E, Segal S. Effectiveness of second-generation fibrin glue in endonasal operations. Otolaryngol Head Neck Surg. 2002; 126: 388-391.

[10] Shaw CL, Dymock RB, Cowin A, et al. Effect of packing on nasal mucosa of sheep. J Laryngol Otol. 2000; 114: 506-509.

[11] Athanasiadis T, Beule AG, Robinson BH, et al. Effects of a novel chitosan gel on mucosal wound healing following endoscopic sinus surgery in a sheep model of chronic rhinosinusitis. Laryngoscope 2008; 118: 1088-1094.

[12] Chung YJ, An SY, Yeon JY, et al. Effect of a chitosan gel on hemostasis and prevention of adhesion after endoscopic sinus surgery. Clin Exp Otorhinolaryngol. 2016; 9: 143-149.
[13] Berlucchi M, Castelnuovo P, Vincenzi A, et al. Endoscopic outcomes of resorbable nasal packing after functional endoscopic sinus surgery: a multicenter prospective randomized controlled study. Eur Arch Otorhinolaryngol. 2009; 266: 839-845.

[14] Gustafson SB, Fulkerson P, Bildfell R, et al. Chitosan dressing provides hemostasis in swine femoral arterial injury model. Prehosp Emerg Care 2007; 11: 172-178.

[15] Cetin M, Ak D, Duran B, et al. Use of methylene blue and N,Ocarboxymethylchitosan to prevent postoperative adhesions in a rat uterine horn model. Fertil Steril. 2003; 80(Suppl 2): 698701.

[16] Wedmore I, McManus JG, Pusateri AE, et al. A special report on the chitosan-based hemostatic dressing: experience in current combat operations. J Trauma 2006; 60: 655-658.

[17] Mariappan MR, Alas EA, Williams JG, et al. Chitosan and chitosan sulfate have opposing effects on collagen-fibroblast interactions. Wound Repair Regen. 1999; 7: 400-406.

[18] Valentine R, Wormald PJ, Sindwani R. Advances in absorbable biomaterials and nasal packing. Otolaryngol Clin North Am. 2009; 42: 813-828.

[19] Somogyvári K, Móricz P, Gerlinger I, et al. Morphological and histological effects of radiofrequency and laser (KTP and $\mathrm{Nd}$ :YAG) treatment of the inferior turbinates in animals. Surg Innov. 2017; 24: 5-14

[20] Guba PM. A novel surgical mesh suitable for laparoscopy, studied on animal model. [Új, laparoszkópos beültetésre alkalmas sérvháló állatkísérletes vizsgálata.] Orv Hetil. 2016; 157: 180-184. [Hungarian]

[21] Gago LA, Saed GM, Chauhan S, et al. Seprafilm (modified hyaluronic acid and carboxymethylcellulose) acts as a physical barrier. Fertil Steril. 2003; 80: 612-616.

[22] Eloy P, Andrews P, Poirrier AL. Postoperative care in endoscopic sinus surgery: a critical review. Curr Opin Otolaryngol Head Neck Surg. 2017; 25: 35-42.

(Piski Zalán dr., Pécs, Munkácsy M. u. 2., 7621 e-mail: zpiski@gmail.com)

\section{„Exitus acta probat." (Ovidius) (Tettet a vég igazol.)}

